\title{
PERAN RADIO KOMUNITAS DWIJENDRA 107.7 FM DALAM PENGEMBANGAN SIARAN KEARIFAN LOKAL BALI
}

\author{
Anak Agung Gede Bagus \\ Program Ilmu Komunikasi,Fakultas Ilmu Komunikasi Universitas Dwijendra Denpasar \\ studiEmail : a.agedebagus19@gmail.com
}

\begin{abstract}
ABSTRAK
Radio komunitas adalah salah satu lembaga penyiaran yang dilegalkan keberadaan dalam UU Penyiaran No.32 tahun 2002. Menurut UU Penyiaran No. 32 tahun 2002 pasal 13, penyelenggara jasa siaran (televisi dan radio).permasalahannya adalah bagaimana Peran Radio Komunitas Dwijendra 107.7 FM Siaran Kearifan Lokal Bali, Tujuan penelitian ini adalah ingin mengetahui bagaimana peran radio komunitas sebagai media untuk pengembangan siaran kearifan lokal. Penelitian ini bersifat deskriptif kualitatif, Subjek penelitian ini adalahpenanggungjawabpenyiaran siaran kearifan lokal, teknik pengumpulan data dilakukan dengan teknik wawancara, teknik observasi, dan teknik dokumentasi. Hasil penelitian menunjukkan peran radio komunitas sebagai media pendidikan diwujudkan dalam bentuk program siaran yang mengangkat budaya lokal, diwujudkan melalui program siaran yang disusun dan sajikan dalam suatu mata acara yang dikemas secara kreatif. Siaran kearifan lokal Radio Komunitas dwijendra $107.7 \mathrm{fm}$ adalah acara Gegitaan.Dimana acara ini disiarkan pada saat siang hari 12.05-14.00 wita.
\end{abstract}

Katakunci :Radio Komunitas, Komunikasi, Kearifan Lokal

\begin{abstract}
Radio community is one of the broadcasting institutions which legalized the existence of Broadcasting Law No.32 of 2002. According to Broadcasting Law No. 32 of 2002 article 13, providers of broadcast services (television and radio). The problem is how the role of the Dwijendra Radio Community 107.7 FM Broadcast Local Wisdom of Bali, the purpose of this study is to find out how the role of community radio as a medium for the development of local wisdom broadcasts. This research is descriptive qualitative, the subject of this research is the person in charge of broadcasting local wisdom broadcasts, data collection techniques are done by interview techniques, observation techniques, and documentation techniques. The results showed that the role of community radio as an educational medium is manifested in the form of broadcast programs that elevate local culture, manifested through broadcast programs that are arranged and presented in a creatively packaged program. The local wisdom broadcast of Radio Community Dwijendra $107.7 \mathrm{fm}$ is an event Gegitaan. Where the event was broadcast during the daytime 12.05-14.00 wita.
\end{abstract}

Keywords : Radio Community, Communication, Local Wisdom 


\section{PENDAHULUAN}

Radio komunitas adalah salah satu lembaga penyiaran yang dilegalkan keberadaan dalam UU Penyiaran No.32 tahun 2002. Menurut UU Penyiaran No. 32 tahun 2002 pasal 13, penyelenggara jasa siaran (televisi dan radio), dibedakan menjadi empat macam: publik, swasta, komunitas dan berlangganan. Sedangkan trend radio yang berkembang di masyarakat saat ini adalah radio publik, swasta, dan komunitas.Radio komunitas yang terbentuk karena adanya komunitas masyarakat memiliki paham tanggung jawab sosial yang berarti bahwa media dikendalikan oleh masyarakat sendiri.

Radio komunitas sebagai industri yang berkonten lokal, menuntut warganya atau komunitasnya untuk berperan aktif dan peduli dalam mengangkat potensi dan kearifan lokal sesuai dengan nilai-nilai lokal dalam berbagai aspek kehidupan. Keberadaan kearifan lokal merupakan hasil dari proses adaptasi turun-temurun dalam periode waktu yang sangat lama terhadap suatu lingkungan yang biasanya didiami ataupun lingkungan dimana sering terjdi interaksi didalamnya. Kearifan lokal sendiri merupakan tata nilai kehidupan yang terwarisi dari satu generasi ke generasi berikutnya yang berbentuk religi, budaya, ataupun adat istiadat yang umumnya berbentuk lisan dalam suatu sistem sosial dimasyarakat (Juniarta, ddk, 2013). Kearifan lokal baru menjadi wacana dalam masyarakat tahun 1980-an, ketika nilai-nilai budaya lokal yang terdapat dalam masyarakat Indonesia sebagai warisan nenek moyang sudah hampir habis digerus arus modernnisasi, yang membuka diri kepada globalisasi, dengan demikian kekayaan budaya lokal, baik berupa kesenian, sastra, hukum adat, di perkirakan sebagai penyebab punahnya budaya nasional (Rosidi, 2011).

Saat ini Radio Komunitas semakin memantapkan perannya dalam proses pembentukan dan menguatkan potensi lokal, menyokong ekonomi kerakyatan, dan melestarikan kearifan lokal sekaligus mendorong terwujudnya aparat yang bersih (Hakam, 2011). Begitu pentingnya eksitensi Radio Komunitas, terutama untuk mengembangkan siaran yang bernuansa kearifan lokal, maka penulis melakukan penelitian yang berjudul "Peran Radio Komunitas Dwijendra 107.7 FM Dalam Pengembangan Siaran Kearifan Lokal Bali”.Permasalahan yang diangkat dalam penelitian ini adalah bagaimana Peran Radio Komunitas Dwijendra 107.7 FM Dalam Pengembangan Siaran Kearifan Lokal Bali?Adapun tujuan dari penelitian ini adalah ingin mengetahui dan mengkaji mengenai Peran Radio Komunitas Dwijendra 107.7 FM dalam Pengembangan Keariafan Lokal Bali. Penelitian ini, diharapkan menjadi data awal bagi pemerintah dalam hal ini Kementrian Komunikasi dan Informatika ataupun pemerintah provinsi Bali dalam menentukan kebijakan untuk pengembangan penyebaran informasi yang efektifitas dan tepat sasaran serta memilihara siaran kearifan lokal untuk membentuk insan yang berkarakter berbudi luhur dalam menghadapi tantangan.

Dari uraian latar belakang diatas maka rumusan masalah dalam penelitian ini adalah : "Bagaimanakah Peran Radio Komunitas Dwijendra 107.7 FM Dalam Pengembangan Siaran Kearifan Lokal Bali?” 
Tujuan penelitian ini adalah untuk mengetahui Peran Radio Komunitas Dwijendra 107.7 FM dalam pengembangan Siaran Kearifan Lokal Bali.

Ruang lingkup penelitian adalah usaha dalam mencari sesuatu yang sebelumnya tidak ada dan teruji mengenai kebenarannya. Maka ruang lingkup yang di kaji adalah untuk mengetahui Peran Radio Komunitas Dwijendra 107.7 FM dalam Pengembangan Siaran Kearifan Lokal Bali.

Manfaat secara teoritas penelitian ini di harapkan bermanfaat bagi pengembangan ilmu komunikasi, khususnya dalam bidang komunikasi massa yang berkaitan dengan media massa Radio. Secara Praktis penelitian ini di harapkan bermanfaat untuk dapat untuk dapat memberikan masukan terhadap penyelenggaraan Radio Komunitas Dwijendra 107.7 FM. Di samping itu dapat juga sebagai bahan informasi kepada Komisi Penyiaran Republik Indonesia.

\section{METODE}

Pemelihan lokasi berkenaan dengan penentuan unit, bagian kelompok, dan tempat dimana orang-orang didalam kegiatan atau peristwa yang ingin diteliti. Penelitian berjudul "Peran Radio Komunitas Dwijendra 107.7 FM dalam Pengembangan Siaran Kearifan Lokal Bali ini mengambil lokasi Radio Komunitas Dwijendra. Penetapan lokasi penelitian ini didasarkan berbagai pertimbangan peneliti terkait keistimewaan Radio komunitas dwijendra. Keistimewaan tersebut antara lain adalah letak dan kondisi geografis radio komunitas dwijendra yang terletak di Jln. Kamboja no.77 DenpasarBali.

Penelitian ini menggunakan pendekatan kualitatif, suatu pendekatan dengan melakukan kajian secara mendalam dengan tidak menggunakan angka-angka tetapi lebih menekankan uraian secara kualitatif dengan maksud menelaah berbagai informasi secara lengkap dan mendalam.

Rancangan yang digunakan adalah semua proses yang di lakukan dalam perencanaan dan pelaksanaan penelitian. Berdasarkan rumusan masalah dan tujuan penelitian ini, maka rancangan penelitian adalah penelitian deskriptif.

Defenisi Konsep Media massa adalah alat yang di gunakan dalam penyampaian pesan-pesan dari sumber kepada khalayak (menerima) dengan menggunakan alat-alat mekanis seperti surat kabar, film, radio, TV (Cangara, 2002). Media massa adalah faktor lingkungan yang mengubah perilaku khalayak melalui proses pelaziman klasik. Membuat radio siaran sebenarnya mudah seseorang atau sekelompok orang yang memiliki hobi siaran radio, pandai " mengutak-atik" perangkat pemancar radio, serta memahami secara teknis dan persyaratannya, dapat membuat siaran dengan mudah. Saat ini, berdasarkan data permohonan pendirian radio komunitas yang diajukan kepada Komisi penyiaran Indonesia (KPI). Kearifan lokal atau juga biasa di sebut dengan local wisdom dapat di pahami sebagai usaha manusia dengan menggunakan akal budinya (kognisi) untuk bertindak dan bersikap terhadap sesuatu, objek atau peristiwa yang terjadi dalam ruang tersebut 
Tujuan pokok kualitatif ini adalah untuk menggambarkan fakta mengenai peran Radio Komunitas dwijendra 107.7 FM dalam Pengembangan Siaran Kearifan Lokal Bali. Yang menjadi subjek penelitian adalah Ibu Nova sebagai penanggung jawab Radio Komunitas Dwijendra 107.7 FM sebagai informan.

Menurut Hasan (2002:86) Sumber data primer adalah data yang diperoleh atau dikumpulkan langsung dilapangan oleh orang yang melakukan penelitian atau yang bersangkutan yang memerlukannya. Data primer diperoleh dari sumber informasi yaitu individu atau perseorangan seperti hasil wawancara yang dilakukan oleh peneliti. Data primer itu antara lain: 1) cacatan hasil wawancara, 2) Hasil observasi lapangan, 3) Data-data mengenai informan.

Sumber data sekunder adalah data yang diperoleh atau dikumpulkan oleh orang yang melakukan penelitian dari sumber-sumber yang telah ada (Hasan 2002:58).Data ini digunakan untuk mendukung informasi primer yang telah diperoleh dari buku-buku maupun dokumen-dokumen yamg memiliki hubungan dengan peran radio komunitas yang dapat membantu memberikan informasi kepada peneliti.

Teknik pengumpulan data yang penulis pakai adalah teknik pengumpulan data kulalitatif.Pengumpulan data dalam betuk kalimat, kata dan gambar. Pelakasanan teknik pengumpulan dapat dilakukan dengan:

Teknik pengumpulan data ini digunakan menjaring data yang diperlukan guna untuk melengkapi data dari wawancara.Observasi merupakan kegiatan pengamatan yang dilakukan oleh peneliti, dimana peneliti berperan dalam lokasi studi sehingga benar-benar terlihat dalam kegiatan yang ditelitinya.Dalam obsevasi ini, peneliti terlibat dengan kegiatan sehari-hari orang yang sedang diamati atau yang digunakan sebagai sumber data penelitian.Observasi dipakai untuk menhami persoalan-persoalan yang ada disekitar pelaku dan narasumber.Peneliti hadir sebagai peneliti murni bukan guru atau siswa.Teknik observasi ini untuk mendapat data tentang langkah-langkah yang dilakukan dalam pembelajaran tematik.Observasi dilakukan dengan terjun langsung ke lapangan secara aktif untuk memperoleh gambaran dan keteranagan riil mengenai sikap dan perilaku informan. Dalam hal ini Radio Komunitas Dwijendra 107.7 FM sebagai tempat penlitian, maka penulis melakukan observasi tentang bagaimana tempat siaran, pengelolaan program siaran kearifan lokal yang ada pada Radio komunitas Dwijendra 107.7 FM. Keterangan dan informasi yang diperoleh kemudian dianalisis, ditafsirkan dan simpulkan. Untuk memperoleh data, peneliti belaku sebagai pengamat sekaligus menjadi anggota utuh dari kelompok yang diamati, sehingga kesan subjektif dapat diredam.

Wawancara merupakan proses pengumpulan data yang memperoleh informasi langsung dari sumbernya. Dengan melakukan wawancara mendalam dimaksudkan dalam rangka memahami pandangan peneliti mengenai hidupnya, pengalamannya ataupun situasi sosial sebagaimana yang ia ungkapkan dalam bahasanya sendiri. Wawancara mendalam dilakukan dengan mengajukan pertanyaan-pertanyaan terbuka yang memungkinkan responden memberikan jawaban secara luas. Data yang diperoleh dari wawancara mendalam berupa pengalaman, pendapat, perasaan dan pengetahuan 
informan mengenai pengelola Radio Komunitas Dwijendra 107.7 FM yang dipilih secara purposif berkaitan dengan aspek peran Radio Komunitas Dwijendra 107.7 FM dalam pengembangan siaran kearifan lokal bali yang dimana informannya adalah penanggung jawab penyiaran Radio Komunitas Dwijendra.

Dokumentasi adalah pengambilan yang diproses melalui dokumen-dokumen.Metode dokumentasi dipakai untuk mengumpulkan data dari sumber-sumber dokumen yang mungkin mendukung atau bahkan berlawanan dengan hasil wawancara (Harsono, 2008:165).Teknik ini dilakukan untuk memperoleh data yang berupa dokumen atau arsip.Metode dokumentasi dilaksanakan untuk melengkapi data yang diperoleh dari wawancara dan observasi. Data yang di peroleh berupa tulisan seperti buku-buku pedoma, surat kabar. Dalam penelitian ini, teknik dokumentasi dilakukan dengan cara mengumpulkan dokumen-dokumen resmi yang berhungan dengan pengembangan siaran kerafian lokal.

Dalam penelitian ini Teknik analisis data menggunakan Analisis Deskriptif kualitatif, yang dimana penulis mendeskripsikan hasil wawancara dengan informan pada Radio Komunitas Dwijendra107.7 FM yang merupakan objek dari penelitian ini. Hasil wawancara yang kemudian akan disusun secara tertulis yang nantinya akan dideskripsikan menurut pertanyaan yang diberikan kepada informan pada saat melakukan wawancara. pengumpulan data dengan wawancara, selanjutnya data akan direduksi dimana reduksi data ini adalah suatu bentuk analisis yang menajamkan , menggolongkan, membuang data yang tidak perlu dan mengorganisasikan data dengan sedemikan rupa sehingga simpulan final dapat ditarik dan diverifikasi, dan data disajikan dalam suatu rangkaian organisasi informasi yang mungkin kesimpulan riset dapat lakukan. Dan kemudian melakukan penarikan kesimpulan. Setelah proses pengumpulan data, reduksi data, hingga akhirnya menetukan kesimpulan. Kesimpulan ditarik setelah peneliti mendapatkan pengumpulan data yaitu wawancara.kesimpulan yang dapat menjurus pada jawaban dari pertanyaan penelitian yang di ajukan pada narasumber.

\section{Hasil Dan Pembahasan}

Radio Komunitas Dwijendra merupakan media pelestari nilai agama, sastra, budaya Bali dan pengetahuan yang informative dan komunikatif. Pengelolaannya diserahkan kepada Unit Pelaksana Teknis Yayasan Dwijendra.Pada tahun 2000, para mahasiswa Fikom Universitas Dwijendra,merintis radio DJ sebagai media untuk pembelajaran penyiaran radio.

Berdasarkan uraian mengenai kearifan lokal, tersebut maka dapat dikatakan bahwa siaran kearifan lokal adalah siaran yang mengacu dan berisi berbagai kekayaan budaya yang yang ada pada masyarakat setempat.Dalam penelitian ini yang bisa diangkat adalah Peran Radio Komunitas Dwijendra 107.7 FM dalam pengembangkan siaran Kearifan Lokal Bali. 
Menurut Ibu Ni Made Adi Novayanti,S.I.Kom (2019) wawancara pada tanggal 1 Juli 2019, Peran Radio komunitas Dwijendra 107.7 FM dalam Pengembangan Siaran Kearifan Lokal Bali.Perkembangan siaran kearifan lokal di radio komunitas dwijendra menunjukkan semangat warga untuk memajukan Radio komunitas cukup tinggi, keberadaannya dapat bertahan karena semangat antara pengelola, penyiar dan antusias pendengar dalam berpartisipasi untuk kelangsungan siaran komunitas ini merupakan konsistensi pengelola memenuhi kebutuhan pendengar akan informasi dan hiburan yang bernuansa lokal, yaitu mengadahkan acara tentang isu penting dalam komunitasnya. Untuk pemenuhan kebutuhan informasi pendengar tertentu diwilayahnya, walaupun penyajian sederhana namun menjadi format unggulan ketika mendapatkan sambutan antusias dari pendengar. Merupakan pembuktian bahwa Radio Komunitas Dwijendra mempunyai kelebihan dari radio komersial lainnya yaitu adanya prinsip dan kedekatan psikoligis fisik, dan budaya. Radio komunitas dwijendra 107.7 fm mempunyai target kelompok pendengar pada komunitas tertentu dalam mengemas program siaran secara kreatif konsisten kental dengan nuansa lokal baik sajian informasi maupun hiburan.

Radio komunitas dwijendra sebagai media pendengar memiliki kewajiban untuk mempertahankan siaran kearifan lokal yang di wujudkan melalui siaran-siaran yang bernuansa lokal, penggunaan bahasa lokal seperti bahasa Bali juga merupakan wujud dari kenginan pengelola untuk mengangkat lokalitas daerah.

Program-program acara tersebut merupakan acara kearifan lokal ditujuhkan dengan diberikannya porsi yang dominan untuk acara tersebut, dalam seluruh isi siaran baik dalam sajian informasi pendidikan, hiburan dan budaya, porsi siaran yang dominan ditunjukkan dari durasi masingmasing acara antara satu hingga dua jam. Dominannya acara atau siaran yang bernuansa lokal bahwa peran Radio Komunitas dwijendra 107.7 fm berusaha menerapkan asap kedekatan psikolgis dan geografis dengan masyarakat setempat.

Peran penanggung jawab dalam mengembangkan siaran kearifan lokal tentu sebelum kita ditugaskan diradio komunitas dwijendra kita harus memahami visi dan misi dari radio komunitas dwijendra dan tentu sangat jelas visi dari dari komunitas dwijendra adalah menjadi radio komunitas yang profesional dan terpercaya dalam memajuhkan dunia pendidikan, sastra, budaya dan agama Hindu Bali. Maka dari itu tentu kita harus mempersiapkan atau harus menyediakan program siaran kearifan lokal.

Pemberdayaan sumber daya manusia, langkah pertama yang harus dilakukan adalah memberikan program-program sebaik mungkin, merebut hati pendengar selanjutnya menjadikan radio komunitas sebagi media yang bisa digunakan dalam mengkatkan wawasan ilmuan dan hiburan yang sehat. Dalam hal peningkatan Mengenai sumber daya manusia (SDM) khususnya penyiar kearifan lokal ini tentunya tidak sembarang. Penyiar harus mengkatkan kualitasnya mulai dari bagaimana 
memahami materi siaran, berbicara yang baik dan benar, menggunakan intonasi yang baik dan benar, melatih vocal, dan mempersiapkan beberapa catatan-catatansebelum bersiaran

Terkait dengan persiapan penyiaran acara kearifan lokal di 107.7 FM ini yang pertama kita bentuk team terlebih dahulu, jadi kita mengundang bapak/ibu guru yang materi muatan lokal, kita undang mereka terlebih dahulu siapa yang kira-kira berkenan untuk mengisi acarakearifan lokal kita, yamg kita punya, yang kita berikan nama acaranya yaitu adalah GEGITAAN. Dulunya dari tahu 2010 sampai 2013, kita punya dua acara kearifan lokal budaya bali yaitu pertama, ada suara Ning Bali, kemudian ada Gegitaan, dengan beriringnya waktu suara Ning Bali kita tiadakan hanya kita fokus kepada Gegitaan, karena Gegitaan ini kita punya kelompok yang benar-benar menyukai adat budaya ataupun juga seni. Seni bali ini yang bernama Gegitaan, rencananya kita kumpulkan bapak/ibu guru yang bersedia hingga akhirnya kita membentuk team baru kemundian kita bisa merancangkan berapa jam mereka ingin bersiaran dan seperti apa format siarannya.

Hambatan lainnya adalah Kondisi cuaca sangat mempengaruhi pelaksanaan program siaran. Menurut Ibu Ni Made Adi Novayanti,S.I.Kom, pelaksanaan program tidak akan memungkinkan on air disebabkan oleh cuaca buruk seprti adanya petir, hujan lebat maupun adanya kerusakan alat. Timbulnya gemuruh dan angin mengakibatkan gelombang yang dipnacarkan menjadi hilang timbul (modulation). Ketika cuaca buruk maka terpaksa siaran dihentikan atau off air. Jika tetap dilanjutkan maka khawatir akan terjadi sesuatu yang tidak dinginkan sperti alat-alat tersambar petir.

\section{PENUTUP}

\section{Simpulan}

Berdasarkan uraian diatas tentang penelitian Peran Radio Komunitas Dwijendra 107.7 FM dalam Pengembangan Siaran Kearifan Lokal Bali dapat disimpulkan sebagai berikut: Radio Komunitas Dwijendra 107.7 FM sudah mempunyai Peran dalam Pengembangan siaran kearifan lokal dapat dibuktikan banyaknya minat dari masyarakat untuk mendengarkan siaran program ini melalui request pendengar. Program dan bentuk siaran kearifan lokal dalam mengangkat budaya lokal diwujudkan melalui program yang disusun dan disajikan dalam suata mata acara yang dikemas secara kreatif dengan konsep interaktif, mngetengahkan siaran kearifan lokal yang bernuansa budaya bali, melalui sajian acara Gegitaan yang di mana acara ini meupakan acara berbasis budaya bali khususnya,acara ini berinteraksi dengan penelpon unutk mengikuti program siaran. Pelaksanaan program siaran sesuai dengan tujuan penyiaran yaitu sebagai media informasi pendikan, media hiburan dan media layana masyarkat. Program siaran kearifan lokal yang disajikan sudah tepat sasaran memontum.Radio Komunitas Dwijendra melibatkan pendengar dalam menyusun program siaran. Hal ini ditunjukkan dengan keterlibatan pendengar Radio komunitas Dwijendra 107.7 FM dalam memberikan aspirasi dan pendapat penysunan program siaran acara kearifan lokal. 


\section{Saran}

Berdasarkan hasil penelitian maka saran yang diberikan penelitian ini sebagai berikut : kepada penanggung jawab penyiaran radio komunitas dwijendra 107.7 FM meningkatkan ide-ide, kreatifitas, inovasi dalam menyusun program siaran serta terus meningkatkan kualitas Sumber Daya manusia dengan dibekali kemampuan dan pengetahuan tentang dunia penyiaran.Kehadiran Radio Komunitas Dwijendra 107.7 FM dalam mengusung isu seni didaerahnya hendak tidak hanya tidak hanya untuk memenuhi kepuasan pendengarnya diharapkan para pengelola dapat menjalankan fungsi radio sesuai harap publik pendengarnya untuk mendapatkan pengetahuan tentang peran siaran kearifan lokal.

\section{DAFTAR PUSTAKA}

Cangara, 2010.Pengantar Ilmu Komunikasi. Jakarta: PT. Raja Grafindo Persada

Effendy, 2003.Ilmu Komunikasi Teori dan Praktek. Bandung: PT. Remaja.Rosda Karya.

Fauziahardiyani, 2009.Komunikasi dan Media. Bandung: PT. Remaja Rosdakarya.

Hakam, 2011.Kongvergensi Media Dalam Radio Komunitas.

Juniarta ddk, 2013.Kajian Profil Kearifan Lokal Masyarakat Pesisir Pulau Gili Kecamatan Sumberasih Kabupaten Probolinggo Jawa Timur. Jurnal ESCSOFiM. Vol. 1 No. 1. 2013

M. Habib Bari, 1995. Teknik dan Komunikasi Penyiar Televisi - Radio - MC. Gramedia Pustaka Utama.

Masduki, 2001.Jurnalistik Radio: Menata Profesionalisme Reporter dan Penyiar Radio. Jakarta: Penebar Swadaya.

McQuil, 1987.Teori komunikasi Massa, Jakarta: Erlangga

Morrisan, 2015.Media penyiaran Strategi Mengelola Radio dan Televisi. Tangerang: Ramdina Prakarsa.

M. Habib Bari, 1995. Teknik dan Komunikasi Penyiar Televisi - Radio - MC. Gramedia Pustaka Utama.

Masduki, 2001.Jurnalistik Radio: Menata Profesionalisme Reporter dan Penyiar Radio. Jakarta: Penebar Swadaya.

McQuil, 1987.Teori komunikasi Massa, Jakarta: Erlangga

Morrisan, 2015.Media penyiaran Strategi Mengelola Radio dan Televisi. Tangerang: Ramdina Prakarsa.

Narudin, 2007.Pengantar Komunikasi Massa. Jakarta: PT. Raja Grafindo Persada

Nurhidayah, 2011.Proposionalitas Tayangan local wisdom (Kearifan local) Jawa Tengah di Stasiun Televisi Borobudur Semarang.Skripsi.Dakwah IAIN Walisongo Semarang. Hal.23 